REVISTA DE LITERATURA E CULTURA RUSSA

\title{
On the sources of nihilism in Dostoevsky's "Crime and Punishment"
}

\section{Sobre as fontes de niilismo em Crime e Castigo de Dostoiévski}

Autor: Markos Galounis

Edição: RUS Vol. 11. No 16

Data: Setembro 2020 


\section{On the sources of nihilism in Dostoevsky's "Crime and Punishment"}

\section{Marcos Galounis*}

\begin{abstract}
It is well known that Dostoevsky's Crime and Punishment reflects the intellectual milieu of the period of its conception. More specifically, the motivation of Raskolnikov's crime is rooted in the nihilism of the radical intelligentsia of the period. In this article, the ideology of Raskolnikov is identified with the ideology of the representatives of the radical intelligentsia, namely Nikolai Chernyshevsky and Dimitri Pisarev. It also traces the continuity and discontinuity of the ideas of these thinkers. Finally, argues that Dostoevsky perceived the evolution and radicalization of the intelligentsia's ideas through the lenses of the evolution and radicalization of the Left Hegelians, namely Feuerbach and Stirner, whose ideology influenced the Russian radical intelligentsia. Thus is brought to the fore the intellectual origins of the Russian radical intelligentsia's nihilism, which was seminal to Dostoevsky's Crime and Punishment.
\end{abstract}

Resumo: Como se sabe, Crime e Castigo, de Dostoiévski, reflete o meio intelectual do período de sua concepção. Mais especificamente, a motivação do crime de Raskólnikov está enraizada no niilismo da intelliguentsia radical do período. Neste artigo, a ideologia de Raskólnikov é identificada com a ideologia de Nikolai Tchernichévski e Dimítri Píssarev, representantes da intelliguentsia radical. Além disso, o artigo traça a continuidade e a descontinuidade das idéias destes pensadores. Por fim, argumenta que Dostoiévski percebe a evolução e a radicalização das ideias da intelliguentsia pelas lentes da evolução e radicalização dos hegelianos de esquerda, isto é, Feuerbach e Stirner, cuja ideologia influenciou a intelliguentsia radical russa. Por isso, são trazidas à tona as origens intelectuais do niilismo da intelliguentsia radical russa, seminal para Crime e Castigo, de Dostoiévski.

Keywords: Dostoevsky; Russian Radical Intelligentsia; Hegelianism in Russia Palavras-chave: Dostoiévski; Intelliguentsia Radical Russa; Hegelianismo na Rússia 
* Postgraduate studies in Philosophy at the University of Warwick, United Kingdom, and graduate of the Department of Byzantine and Modern Greek Studies of the University of Ioannina, Greece; markosgalounis@yahoo.com

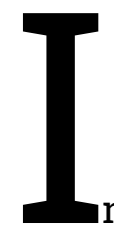

a well-known letter to Katkov, which was meant to convince him to publish "Crime and Punishment", Dostoevsky described the novel he intended to write as a "psychological account of a crime ... The action is topical, set in the current year. A young student of lower-middle-class origin, who has been expelled from the university, and who lives in dire poverty, succumbs - through thoughtlessness and lack of strong convictions - to certain strange, "incomplete" ideas that are floating on the air, and decides to get out of his misery once and for all." In what follows, I will try to identify these "'incomplete" ideas that are floating on the air" during the period of conception of the novel and also to examine the way in which Dostoevsky drew his inevitable conclusions from them when he "completed" them.

As is known, the two ideological sources of motivation that led Raskolnikov to commit a crime were the utilitarian motive and the Napoleonic motive. Both motives have been associated with two well-known members of the Russian radical intelligentsia of the 1860's - the former with Nikolai Chernyshevsky, and the latter with Dmitri Pisarev, as Joseph Frank has shown. ${ }^{2}$

In his thesis "The Anthropological Principle in Philosophy", which was published in 1860, five years before the publication of "Crime and Punishment", Chernyshevsky endorses an unrestricted naturalism grounded in scientific materialism. Scientific materialism seemed to provide ammunition with which to fight any idealistic or religious, elevated view of man.

\footnotetext{
1 Letter sent to Katkov during the first half of September 1865, when "Crime and Punishment" was in its inception. In eds. Joseph Frank and David Goldstein, tr. Andrew MacAndrew, Selected Letters of Fyodor Dostoevsky (Rutgers University Press, New Brunswick and London, 1987), p. 221.

2 Joseph Frank, Dostoevsky, vol. 4, The Miraculous Years, 1865-1871 (Princeton University Press, Princeton, 1995), pp. 60-79.
} 
Hence, in keeping with this naturalism, among other things, Chernyshevsky proclaimed that there is no line of demarcation between animals and humans, that free will is abolished in favour of a deterministic view of human agency, and, finally, that acts mistakenly understood as manifestations of altruism are in fact acts of egoism masquerading as the former:

"People learned from experience that every man thinks only about himself, is more concerned about his own interests than he is about the interests of others, that he nearly always sacrifices the interests, honour and life of others to his own. In short, everybody learned that all people are egoists."

We should bear in mind that the role of the intelligentsia was conceived of as destructive, namely to demolish idealistic and metaphysical prejudices of the past that were seen as pillars of the autocracy and the Church. Science and naturalism were seen as allies in the destruction of any last remnants of idealism. As David Benthea and Victoria Thorstensson write: "Natural science provided what appeared to be an indispensable means of organizing the material of life in a manner that applied to all; it was meaningful in that it made sense, and it was democratic in that it only recognized its own authority, not that of the Church, state, or traditional metaphysics." That is exactly what Chernyshevsky did when he set allegedly scientifically proven egoism against traditional, religious conceptions of altruism. But destruction was conceived of as just a moment, a prelude to a new, promising life that was awaited after the ground was cleared. After all, it was Turgenev in "Fathers and Sons" who castigated the young people by claiming that they did not have any plan for reconstruction after the ground was cleared.

"At the present time, negation is the most useful of all... That's our business now... The ground has to be cleared first.".5

3 Nikolai Chernyshevsky, "The Anthropological Principle in Philosophy", in Selected Philosophical Essays (Foreign Languages Publishing House, Moscow 1953), p. 120.

4 David Bethea and Victoria Thorstensson, "Darwin, Dostoevsky, and Russia's Radical Youth", Dostoevsky beyond Dostoevsky. Science, Religion, Philosophy, ed. Svetlana Evdokimova and Vladimir Golstein (Academic Studies Press, Boston 2016), p. 38.

5 Ivan Turgenev, Fathers and Sons, The Author on the Novel, Contemporary Reactions, 
In "What is to be Done?", which was destined to become the most influential Russian novel of the 19th century, Chernyshevsky took up Turgenev's idea that negation does not necessarily contain the seeds of a new beginning and what will follow is unclear and qualified the egoism he had endorsed five years previously in the "Anthropological Principle of Philosophy" as a rational egoism. Rationality will reconcile individuality with the collectivist values that Chernyshevsky, like all the members of the intelligentsia, espoused and would be conducive to the harmonious cooperation of interests in society. In addition, rationality would lead egoists to behave altruistically, once they came to know their true interest. Egoism would thus be transformed into self-abnegating altruism.

Alongside rational egoism, the second constitutive element in Chernyshevsky's novel is the prominent, almost worl$\mathrm{d}$-historical role he bestowed upon the intelligentsia. As the prospect that the peasant movement might lead to a general revolution began to fade following the first years of reforms and the regime simultaneously became increasingly strict, the tiny section of the population that comprised the intelligentsia, the new people, were elevated to the status of the only bearers of hope. "The new people", write Katz and Wagner, "would reshape rather than simply react to the Russian environment... [This signalled both] a sense of mission, as well as alienation from the state and the rest of society." ${ }^{\prime \prime}$

Hence, we can identify an intrinsic tension in the thinking of Chernyshevsky. Egoism, whether qualified as rational or not, must fulfil the needs of the individual while also simultaneously underpinning his collectivist aspirations. Egoism is both individualistic and understood as providing the foundations for a society based on a harmonious cooperation of interests. It has to be simultaneously, individualistic and democratic.

Essays in Criticism, ed. And tr. Ralph Matlaw, New York, Norton, 1966, p. 39, cited in Michael Allen Gillespie, Nihilism before Nietzsche, the University of Chicago Press, Chicago 1995, p. 147.

6 Michael Katz and William Wagner, "Chernyshevsky, What is to be Done? And the Russian Intelligentsia", in Nicolai Chernyshevsky, What Is To Be Done?, tr. Michael Katz (Cornell University Press, Ithaka and London 1989), pp. 20 and 2. 
Dmitry Pisarev and other authors who wrote for the journal The Russian Word [Russkoe Slovo], would further radicalize the ideas of Chernyshevsky. Thus, for Pisarev and the other contributors to The Russian Word, the emancipation of the individual from the fetters of society - an intrinsically elitist value - would become an end in itself. It could no longer underpin collective ideas, such as agrarian socialism with its concomitant glorification of the Russian peasantry, which Chernyshevsky endorsed. "The Nihilists in the Russkoe Slovo," writes Venturi, "put their trust and hopes mainly in themselves. They refused to believe either in the ruling classes or even in the myth of "the people" and "the peasants". The "emancipation of the person", (i.e. the formation of independent characters "who think critically"), was more important than social emancipation." " With this loss of populist values, the rift between the intelligentsia and the people would become unbridgeable. Zaitsev, who also wrote for The Russian Word, would even endorse Social Darwinism - a true anathema to any populist ideology. In addition, Zaitsev would adopt Jacobinism. For he insisted that the new members of the intelligentsia should not love the people, but rather act on their behalf. Echoes of Zaitsev's Social Darwinism, with its intrinsic contempt for the people, have been identified in Crime and Punishment, in Raskolnikov's Napoleonic motive, namely the division of humanity into "ordinary" and "extraordinary" people. ${ }^{8}$

Dostoevsky followed closely the rift between the radicals of Chernyshevsky's The Contemporary and Pisarev's The Russian World, dubbing it "the schism [Raskol] between the nihilists", in an article published in his journal in $1863 .{ }^{9}$ As known,

\footnotetext{
7 Franco Venturi, Roots of Revolution. A History of the Populist and Socialist Movements in Nineteenth Century Russia, tr. Francis Haskell (Weidenfeld and Nicholson, UK, 1960), p. 317.

8 See David Bethea and Victoria Thorstensson, "Darwin Dostoevsky and Russia's Radical Youth", pp. 41-45.

9 On the rift between "The Contemporary" and "The Russian Word", for which Chernyshevsky and Pisarev wrote respectively, see N.G.O. Pereira, "Challenging the principle of Authority: The polemic between Sovremennik and Russkoe Slovo, 1863-1865", The Russian Review, (vol. 34, no.2, April 1975), pp. 137-150. For Dostoevsky's article see F.M.Dostoevsky, "Gospodin Shchedrin, ili raskol v nigilistakh" in Polnoe sobranie sochinenii, 30 vols. (Nauka, Leningrad, 1972-90, vol. XX), 102-4, cited in Richard Peace, "Nihilism" in A History of Russian
} 
in "Notes from the Underground" (1864), Dostoevsky would sharply criticize (and mock) the first component of Chernyshevsky's rational egoism, namely rationality. In Crime and Punishment, published between 1865 and 1866, he would challenge Chernyshevsky from another angle. That is to say, as I wish to argue, he now sees the radical intelligentsia's rift between Chernyshevsky and Pisarev through the prism of a previous rift that took place between two German Left Hegelians, namely, Ludwig Feuerbach and Max Stirner. Dostoevsky thus sees the passage from Chernyshevsky's rational egoism to Pisarev's elitism, that signalled the degeneration of the populist collective values of the intelligentsia, through the lens of the degeneration of Feuerbach's anthropology to Stirner's egoism.

It is rarely noted that what sustained the collectivist aspiration of Chernyshevsky's egoism was not only rationality, but also the social character of Feuerbach's anthropology. The strong influence of Feuerbach on Chernyshevsky is evidenced by the very title of Chernyshevsky's thesis, "The Anthropological Principle of Philosophy". The fact that, in spite of the allusion in the title, Feuerbach's name and his anthropology are conspicuously absent in the actual content of the essay, is due to the fear of censorship. Chernyshevsky hints at this when he addresses the reader just a few pages before the end of his essay:

"But we have almost forgotten that the term "anthropological" in the heading of our essays has still remained unexplained. What is this "anthropological principles in moral sciences"? The reader has seen what this principle is from the very character of the essays." ${ }^{10}$

Similarly, in What is to be Done? (1863), written when Chernyshevsky was in jail, again out of a fear of censorship, the name of Feuerbach is only hinted at and appears clothed in Aesopian language.

Thought, ed. William Leatherbarrow and Derek Offord (Cambridge University Press, USA 2012), p. 139, n. 64. 
"Maria Ivanych read the title [of the book] slowly: "On religion", by Ludwig, that is, Louis XIV, Marya Aleksevna. It's a book by Louis XIV. He was king of France, Marya Aleksevna."11

The fact that the main idea can be only hinted at, clothed in Aesopian language out of a fear of censorship, is stated openly, and surprisingly so, given that Dostoevsky was an former political convict and under surveillance - in Crime and Punishment. Raskolnikov's main Napoleonic idea is alluded to towards the end of his published article, and Porfiry's attention is drawn, not to the main bulk of the published article, but to an obscure allusion.

"Most, most original, but... that wasn't actually the part of your little article that interested me so much. It was rather a certain idea that you introduced at the end of the piece, but which you unfortunately alluded only to passing." ${ }^{12}$

Raskolnikov admits the published article contains only an indirect allusion to his Napoleonic idea:

"None of that's actually in the article, it's merely alluded to, obscurely."13

And he explicitly attributes its incompleteness to the fear of censorship:

"I don't even think that the article which said that would be allowed into print." ${ }^{14}$

We must remember that censorship was tightened after 1862 , something that is mentioned in the novel in passing, when Svidrigailov says to Raskolnikov: "I wonder if you remember how, a few years ago, when we were still in the era of beneficent glasnost..." ${ }^{15}$

We could say that Porfiry (and implicitly the readers of the novel) is being invited to engage in a form of interpretation that resembles a decoding.

11 Nikolai Chernyshevsky, What Is To Be Done?, 112

12 Fyodor Dostoevsky, Crime and Punishment [hereafter referred to as CP, tr. David McDuff, Penguin 1991, Part 3, chapter 5, p. 311.

13 Fyodor Dostoevsky, CP, Part 3, Chapter 5, p. 316.

14 Fyodor Dostoevsky, CP, Part 3, Chapter 5, p. 312.

15 Fyodor Dostoevsky, CP, Part 4, Chapter 1, p. 339 
We shall therefore examine briefly Feuerbach's philosophy that was fundamental for Chernyshevsky. We will then look at its criticism by Stirner and, finally, we will examine the way it is reflected in Dostoevsky's "Crime and Punishment".

Feuerbach's new philosophy was based on a radical critique of religion and a simultaneous humanist or anthropological interpretation of the human experience. According to Feuerbach's "Essence of Christianity", which was published in 1841, religion objectifies humanity's essence, such that the "divi$n e$ " is only a projection of the "human" reflected in an ideal form. "One of Feuerbach's primary objectives in the "Essence of Christianity" was to demonstrate that the alleged universal "objects" to which man related in religion and theology were illusions. These "objects" were "nothing else than the subject's own nature taken objectively"; they were "objectifications" of man's own essential nature as a rational, emotive and volitional being," John Toews writes. ${ }^{16}$

Man's liberation is nothing other than a reclaiming of attributes traditionally assigned to God. So the emancipating role of philosophy consists in the healing of man's alienation through the transformation of religion to anthropology. In Feuerbach's own terms: "Man is the God of Men." ${ }^{17}$ With Feuerbach's transformation of theology into anthropology, the real essence of Christianity no longer resides in the God-man but in man as man. We have a twofold act: a divinization of man, who, in a Promethean way, usurps the predicates traditionally attributed to God, and a simultaneous humanization of philosophy. We recall that the title of Chernyshevsky's thesis was 'The Anthropological Principle in Philosophy."

Once Anthropology replaces theology and becomes the prevailing explanation of man, the role of faith in Christianity is replaced by "love". Instead of saying "God is love", Feuerbach's humanism merely inverts the subject and the predicate and

16 John Edward Toews, Hegelianism. The path toward dialectical humanism, 1805-1841, Cambridge University Press, USA 1980, p. 342.

17 Cited in John F. Welsh, Max Stirner's Dialectical Egoism, A New Interpretation, Lexington Books, UK, p. 17 
asserts that "love is the supreme being". Love, unmediated by any external entity such as the Church or tradition, becomes the new faith of this form of humanism. "Just as he who has experienced love has experienced everything," Feuerbach wrote, "so he who has comprehended love has comprehended everything; comprehend love and you have comprehended God and everything." ${ }^{18}$

Feuerbach's influence on the novel is evidenced by the name of the goddess in Vera's first dream. The goddess says: "I have many different names. I tell each person the name he should use. You shall call me Love of Humanity. That's my real name."19

The elevation of love to the essence of human feeling in Feuerbach's humanism also has strong social implications as the individual transcends himself through the self-sacrificing activity of love in order to form a post-Christian social order. "This process of human self-actualization and self-knowledge could be conceived only as a collective act of a "we"' rather than "'I"', writes Toews. ${ }^{20}$ It is significant that Chernyshevsky, in his novel echoing Feuerbach's collective ideal sustained by his notion of love, names the goddess in Vera's first dream "Love of Humanity": "I have many different names. I tell each person the name he should use. You shall call me Love of $\mathrm{Hu}-$ manity. That's my real name."21

In an insightful essay, Sergei Kibalnic indicates the pivotal role Feuerbach's notion of love for humanity plays in "The Brothers Karamazov."22 For Dostoevsky, love of humanity is inept if it is not accompanied by a belief in the immortality of the soul. It is non-coincidental, as Kibalnic observes, that the two people that endorse the Feuerbachian notion of love for

18 Cited in John Edward Toews, Hegelianism, p. 195.

19 Nikolai Chernyshevsky, What Is To Be Done?, p. 131.

20 John Edward Toews, Hegelianism, p.345.

21 Nikolai Chernyshevsky, What is to Be Done?, p.131.

22 Sergei Kibalnic, "If there's no immortality of the soul,... everything is lawful": On the Philosophical Basis of Ivan Karamazov's idea", Dostoevsky Beyond Dostoevsky. Science, Religion, Philosophy, pp. 165-176. 
humanity in "The Brothers Karamazov," namely Rakitin and Madame Khokhlakov, are both depicted with a touch of irony. A trace of irony is also evident in the confession of a doctor, related by Zosima: "I love humanity," he said, "but I wonder at myself. The more I love humanity in general, the less I love man in particular." ${ }^{23}$

More prosaically and directly in his The Diary of a Writer, Dostoevsky again refers to Feuerbach's notion of love of humanity:

"Those people who deprived humanity of its faith in its own immortality want to replace that faith, in the sense of the meaning of the highest purpose of existence, by "love for humanity," those people, I say, are raising their hands against themselves; for in place of love for humanity they plant in the heart of one who lost his faith the seed of hatred for humanity."24

The elevation of love to the essence of human feeling in Feuerbach's humanism also has strong social implications. "If instead of saying God is love, it is asserted that love is divine, then love for the essence of man becomes the basis of transforming social relations and recreating post-Christian social order," writes John Welsh. ${ }^{25}$

The philosophy of Feuerbach was influential in the circle of Belinsky, of which the young Dostoevsky was part in the 1840's. But a book by another Left Hegelian, The Ego and its Own, by Max Stirner, published in 1845, strongly criticizing Feuerbach's philosophy, was also read in this very same circle. This book was translated into Russian and was received with awe by Belinsky, for, as we shall see, the type of egoism promoted by Stirner cancelled any collectivistic aspirations intrinsic to Feuerbach's philosophy. Annenkov recalls the huge impact Stirner's book had on Belinsky: "After becoming

23 Cited in Sergei Kibalnik, "If there's no immortality of the soul,... everything is lawful": On the Philosophical Basis of Ivan Karamazov's Idea," p. 174.

24 Cited in Sergei Kibalnic, "If there's no immortality of the soul,... everything is lawful": On the Philosophical Basis of Ivan Karamazov's Idea bid., p. 174.

25 John F. Welsh, Max Stirner's Dialectical Egoism. A New Interpretation (Lexington Books, UK, 2010), p. 66. 
acquainted with Stirner's book, Belinsky took closely to heart the problem it raised and tried to find its solution. It turned out that there was a very important moral question in it for him." ${ }^{26}$ Another possible source of Dostoevsky's knowledge of Stirner's book was Petrashevsky's gatherings and, more specifically, N. Speshnev, who had an influence on the young Dostoevsky and who, as Kibalnic notes, like many other members of Petrashevsky's circle, shared Stirner's ideas. ${ }^{27}$

Stirner criticized all the main tenets of Feuerbach's philosophy, the transformation of theology into anthropology and the notion of "love of humankind", understood as a foundation for a society of the future. Regarding the transformation of theology into anthropology, Stirner rejected the idea that Feuerbach had produced a critique of religion, instead asserting that it had merely reproduced the central features of Christianity. It may be true that Feuerbach rejected God as a transcendent subject, but by projecting the divine predicates onto man, he was preserving a trace of the sacred, now attributed to man. As David Leopold says: "Because Feuerbach's transformative criticism leaves the divine predicates untouched, he is charged with allowing the sacred to remain, if not as God then as 'Man with a capital M!'." Feuerbach had not revealed human nature as it was, but rather deified a purely prescriptive account of what being human involved. Thus leaving the "real kernel"' of religion, the positing of an "essence over me"' (p. 46), intact. Feuerbach's achievement was a "change of masters" (p.55), that actually established a more complete tyranny than before, tying the individual even more securely to a divine ruler. ${ }^{28}$ For Stirner, Feuerbach's attempt to create a new humanism is really only a resurrection of religion, because it

26 P.V. Annenkov, The Extraordinary Decade, Literary Memoirs, tr. Irwin B. Titunik (Ann Arbor, The University of Michigan Press, USA 1968), p. 211.

27 Sergei Kibalnic, "If there's no immortality of the soul... everything is lawful": On the Philosophical Basis of Ivan Karamazov's Idea,", p. 169. For Stirner's influence on Dostoevsky, see also Takayoshi Shimizu, "Dostoevsky and Max Stirner", paper given at the XIV International Dostoevsky Symposium, Naples, June 2010, Abstracts, ed. Michela Vendith, p. 102.

28 David Leopold, "Introduction", in Max Stirner, The Ego and Its Own, tr. Steven Tracy Byington, ed. David Leopold, Cambridge University Press, 1995, p. xx. The citations are from Max Stirner, The Ego and its Own, pp. 55, 46 and 55 respectively. 
intends to transform the human into the divine. Feuerbach's humanism, merely destroyed the old gods, while creating a new supreme being: Man.

In place of Feuerbach's idealized humanism, Stirner posits the particularity of the ego and its own. The person who asserts ownership over his or her life, body, values and identity

recognizes nothing but himself. He does not need to free himself because at the start he rejects everything outside himself because he prizes nothing more than himself - because he starts from himself and comes to himself... Owness is my whole being and existence, it is I myself. I am free of what I am rid of, owner of what I have in my power and control. My own I am at all times and under all circumstances, if I know how to have myself and I do not throw myself away on others." ${ }^{29}$

As Toews says: "Stirner, like Nietzsche, conceived the emergence of the sovereign individual who was the self-sufficient, self-affirming master of his own world as the highest product and imminent telos of world history and psychological development, as the "laughing heir"' of the millennial labors and sufferings of humankind.

Stirner's belligerent and rhetorical affirmation [was] that the ephemeral present existence of the continually self-creating and self-consuming individual ego was the only "absolute" reality in a universe finally stripped of the last illusions of the sacred." ${ }^{30}$

In addition, Stirner dismisses Feuerbach's generalized, universal, abstract love as a form of piety. It becomes a "fixed idea", once fanatical loyalty to the humanist spooks replaces fanatical loyalty to the spooks of religion. It is reflected in everyday life as morality, which becomes the new piety of humanism. "Moral faith is as fanatical as religious faith", ${ }^{31}$ and morality is the most fixed of ideas in modernity. Abstract love and morality become the primary forms of social control over any manifestations of transgression, egoism or individuality.

29 Max Stirner, The Ego and its Own, pp.149 and 143.

30 John Edward Toews, Hegelianism, p. 368.

31 Max Stirner, The Ego and its Own, p. 45. 
Stirner discerned two kinds of love. The "bad case" was Feuerbach's concept of love, in which the ego is sacrificed. Opposed to this is his version of love, the egoistic love, which does not involve the sacrifice of our autonomy. In Stirner's conception of egoistic love, self-mastery is to be attained and preserved against any danger of subordinating oneself to external or internal authorities. Egoistic love demanded "not only that we avoid subordinating ourselves to others, but also that we avoid submitting to our own appetites or ends," says Leopold. ${ }^{32}$ Self-mastery, seen as a constant achievement of the ego, distinguishes egoistic love, on the one hand, and traditional conceptions of love, one the other. "I am my own only when I am master of myself, instead of being mastered... by anything else". ${ }^{33}$ In egoistic love, the way in which the ego relates to others is "enjoyment", and the way in which it relates to itself is by acquiring an emotional detachment towards its appetites and ideas, instead of being dominated by them. We shall return to this tenet of Stirner's egoistic love later.

Finally, Stirner's conception of egoism also has political implications that place him again in opposition to Feuerbach. If what was "God" and "heaven" among the ancients is "humanity" and "society" among the moderns, and the last two are understood to have social control functions, then Stirner's ego signals a resistance to both religious mystification and political dominion. "The unique one" exists in opposition to the state and society. He asserts uniqueness and independence from cultural and collectivist constructs and societal constraints: "The own will of me is the state's destroyer; it is therefore denounced by the state as "self-will". Own will and state are powers in deadly hostility, between which no "perpetual peace" is possible." ${ }^{\prime 34}$

As John Welsh says, "Stirner thus posited a fundamental opposition between society and the individual. But unlike other theorists, Stirner saw no need to reconcile the two, or

32 David Leopold, "Introduction", p. xxiii.

33 Max Stirner, The Ego and Its Own, p. 153,

34 Max Stirner, The Ego and Its Own, p. 175. 
to resolve the contradiction in favor of society or a presumed reciprocity between society and the individual... Stirner reframes the relationship between the individual and society as a conflict over ownership or owness." ${ }^{35}$ Being in perpetual conflict with the state, Stirner's ego does not recognize any sort of obligation whatsoever, including the obligation to obey the law. Instead of a reconciliation between the two, the annihilation of the state is proposed:

"Therefore, we two, the state and I, are enemies. I, the egoist, have not at heart the welfare of this 'human society'. I sacrifice nothing to it, I only utilize it; but to be able to utilize it completely, I transform it rather into my property and my creature; that is, I annihilate it, and form in its place the Union of Egoists." ${ }^{36}$

It is no coincidence that, Stirner, given his aspiration to achieve the emancipation of the individual from all communal ties, rejected the contemporary forms of socialism and communism which other Left Hegelians had endorsed, as secular religions. "The tasks of revolution, however, demanded self-renunciation devotion to a common goal, commitment to supra-personal values, belief in an objective meaning in history - that is, a denial of precisely those values of individual autonomy that Stirner endorsed," writes Toews.$^{37}$ Needless to say this fundamental conflict between society and Stirner's ego renders any conception of society problematic. And it is precisely, Stirner's effort to conceive of a society based on a union of egoists that has been criticized as unfeasible - and this issue is reflected in Crime and Punishment, as we shall see presently.

Returning to Dostoevsky's novel, we see that both of Raskolnikov's motives - the utilitarian taken from Chernyshevsky and the Napoleonic, taken from Pisarev - have an intrinsic humanistic and social value. While with the utilitarian motive the societal dimension is apparent (to do one bad action in order to expiate it with more good ones), with the Napoleonic

35 John Welsh, Max Stirner's Dialectical Egoism, pp. 94-5 and 96.

36 Max Stirner, The Ego and its Own, p. 161.

37 John Edwards Toews, Hegelianism, p. 369. 
it is latent. Besides its strong existential dimension, namely that Raskolnikov kills in order to test with his deed whether he is a Napoleon or a louse, the models deemed transgressors of humanity step over conventional morality in order to reshape society according to their laws, in very Promethean way. Thus the shift from the utilitarian to the Napoleonic does not risk their societal dimension degenerating into bare egoism. As we have already seen both are posited within the philosophy of Feuerbach and its collectivist dimension which influenced Chernyshevsky.

It has been noted many times that the real transgressor of the novel is not Raskolnikov but Svidrigailov. Dostoevsky introduces him masterfully in the middle of the novel with a highly symbolic stepping over ("perestupat"' in Russian), which is related to the Russian word for crime ("prestuplenie" in Russian). "Suddenly, he stepped cautiously over the threshold [and] closed the door carefully after him" ${ }^{38}$ Svidrigailov haunts Raskolnikov in the second half of the novel, the latter constantly oscillating between the former's egoism and Sonya's Christian altruism. Svidrigailov's egoism is bare, devoid of any qualification like "rational" that would ameliorate it, as in Chernyshevsky's philosophy, and attune it to the collectivist ideal. I would like to argue that it is precisely Stirner's egoism that is the source for modeling Svidrigailov's bare egoism.

Significantly, in the same way that Stirner accused Feuerbach of being a crypto-theologian for having offered anthropotheism rather than atheism - a common charge with which every Left Hegelian would label the others - in "Crime and Punishment," Svidrigailov discerns and mocks the humanitarian and idealistic premises of Raskolnikov's convictions. Characteristically on three occasions, he taunts Raskolnikov by calling him a Schiller, that is to say an idealist and romantic: "A Schiller, a Russian Schiller, no less." ${ }^{\text {39 }}$ A little later: "Every

38 CP, Part 3, Ch. 6, p. 332.

39 CP, Part 6, Ch. 4, p 556. Malcolm Jones takes those references to Schiller to be evidence of Raskolnikov's humanitarianism. See Malcolm Jones, "Raskolnikov's Humanitarianism" in Raskolnikov and Svidrigailov, ed. Harold Bloom, (Chelsea House, USA, 2004), pp. 37-49. 
few moments that Schiller in you keeps getting into a tizzy."40 Despite Raskolnikov's transgression, he still retains a residue of moral feeling, accompanied by an elevated belief in humanity. And it is precisely here that his ordeal takes place. Svidrigailov once more discerns this and mocks Raskolnikov: "I understand the kind of problems that are currently on your mind: they are moral ones, aren't they? Problems to do with man as citizen? Oh, put them to one side: why should you bother with them now? Hee, hee! Because you are still a man and a citizen?"41 Raskolnikov remains "a man and a citizen", whereas Svidrigailov endorses an unqualified vision of man. When he first meets Raskolnikov, he cites the Latin poet Terence: "If you will only bear in mind that I am a human being, et nihil humanum." ${ }^{2}$ (The complete extract is: "Homo sum, et nihil humanum a me alienum puto", which translates as: "I am a human being and consider nothing do with humanity outside my province.") ${ }^{43}$ Svidrigailov's vision of humanity is simultaneously broad and limited. It encompasses everything within the domain of the human condition without any moral, political or metaphysical qualification. At the same time, it is limited in the sense that the outcome of this, à la Stirner, is a diminution of the idea of Man to a bare and solipsistic egoism. And there is a strong anti-metaphysical tenor to Svidrigailov's discourse, as reflected for example in his iconoclastic vision of eternity as a bathhouse, with which once more he provokes Raskolnikov. ${ }^{44}$

If my reading is correct, Dostoevsky, by viewing the trajectory of the radical intelligentsia's thought in "Crime and Punishment" through the lens of the passage from Feuerbach to Stirner, turns the populism of the radicals on its head. What began as a humanistic transformation of theology into anthropology and an effort to ground a collective conception of

40 CP, Part 6, Ch. 5, p. 559. See also CP, Part 6, Chapter 3, p. 554.

41 CP, Part 6, Ch. 4, p. 559.

42 CP, Part 4, Ch. 1, p. 337. Italics in the original.

$43 \mathrm{CP}$, p. 237, note 5.

44 CP, Part 4, Ch. 1, p. 337. 
society on the concept of love of humanity, ends in a nihilistic and deeply asocial conception of Man. And, Dostoevsky not only charts this trajectory, he also presents it as inevitable. Chronicles of the Left Hegelian thought interpret the passage from Hegel to Stirner through Feuerbach, and the diminution and degeneration of Hegelianism into nihilism, as inexorable. Stirner appears as "the last link of the Hegelian system" for Avron, ${ }^{45}$ or "the ultimate logical consequence of Hegel's historical system" for Lowith. ${ }^{46}$

However, Dostoevsky does not merely employ Stirner's egoism in order to undermine the traces of Feuerbach's influence on the radical intelligentsia. He also delivers a sharp criticism to Stirner in the novel. As I have argued, Svidrigailov's bare egoism is a fictional rendering of Stirner's conception of ego set, which is posited against the humanitarian and populist element of Raskolnikov's ideology. But it is precisely this bare egoism that has to be refuted as such. Svidrigailov falls in love with Dunia. And when he cannot possess the object of his desire, he uses bribery, blackmail and, in the last resort, violence. It would not be an exaggeration to label the scene between Svidrigailov and Dunia a Dostoevskian rendering of the struggle for recognition, as it is cast in the master and slave dialectic in Hegel's "Phenomenology of Spirit." (Although it is possible Dostoevsky never read Hegel. ${ }^{47}$ In this scene, Svidrigailov becomes aware of this "dialectical" interchange of roles when he wonders about himself: "Am I a monster or am I myself a victim?"48 Svidrigailov appears to be besotted with Dunia and thus unable to demonstrate the necessary emotional detachment from his appetites which, as we have seen in

45 Henri Avron, "Max Stirner", Paris 1954, cited in Lauwrence S. Stepelevich, "Max Stirner and Ludwig Feuerbach."

46Journal of the History of Ideas, vol. 39, 1975, p. 451.

Karl. Lowith, From Hegel to Nietzsche, (New York, 1964), p, 177. Cited in Lawrence Stepelevich, Max Stirner and Ludwig Feuerbach, p. 452, n. 3.

47 While Dostoevsky had probably never read Hegel, he would most likely have been familiar by hearsay with the fundamentals of Hegel's philosophy. On this issue, see Malcolm Jones, "Some echoes of Hegel in Dostoevsky", The Slavonic and East European Review, (vol. 49, no. 117, Oct. 1971), pp. 500-520.

48 CP, Part 4, Ch. One, p. 337. 
Stirner's philosophy, was a prerequisite for egoistic love. And when his love for Dunia is not reciprocated, when he cannot possess the object of his desire, he commits suicide. It is this love, this human, all too human love, the opposite of egoistic love, which becomes the Achilles heel of his egoism for it makes him realize the impossibility of a self-sufficient and solipsistic ego in a quintessentially inter-subjective world.

In "Crime and Punishment", besides egoism, another seminal idea of Stirner is refuted: the union of egoists, considered by its author as constituting the grounds for a society of the future. Just a few pages before Raskolnikov's final conversion and repentance in the epilogue of the novel, Raskolnikov has a dream. In this dream people are infected with an unprecedented plague that makes them go insane:

"But never, never had people considered themselves so intelligent and in unswerving possession of the truth, as did those who became infected. Never had they believed so unswervingly in the correctness of their judgments, their scientific deductions, their moral convictions and beliefs... All were in a state of anxiety and no one could understand anyone else, each person thought that he alone possessed the truth and suffered agony as he looked at the others, beating his breast, weeping and wringing his hands. No one knew how to make the subject of judgment, or how to go about it, no one could agree about what should be considered evil and what good."49

It would not be an exaggeration to construe this dystopian dream as a Dostoevskian refashioning of Hobbes's state of nature. It signifies the relapsing of a society to a "bellum omnium contra omnia", once the presumed solipsistic egoisms are in conflict and cannot reach a basic consensus as to "what should be considered evil and what good" in order to found a feasible society. This dystopian dream can be read as Dostoevsky's fictional rendering of the impossibility of Stirner's union of egoists. And it is significant that, after this dream Raskolnikov, realizes the futility of his ideas, more precisely the futility of the Napoleonic motive, and eventually genuinely repents.

49 CP, Epilogue, p. 626. 
To conclude we have seen how Dostoevsky perceived the trajectory of the Russian radical intelligentsia from Chernyshevsky to Pisarev as a reflection of the movement of Left-Hegelianism from Feuerbach to Stirner. Moreover, he discerned Feuerbach's influence on Chernyshevsky and applied Stirner's criticism of the former to the latter. He construed the degeneration of Chernyshevsky's rational egoism to a bare, unqualified egoism, as is found in Stirner's thinking, as inevitable. But he did not merely employ Stirner's thinking in order to criticize Chernyshevsky; he also challenged two of Stirner's seminal ideas: egoistic love and the union of egoists. In other words, in Crime and Punishment, we find a reflection of how Hegel was received in Russia. "Previously there used to be Hegelians, now they are nihilists", says Pavel Petrovich in Turgenev's Fathers and Sons..$^{50}$ In "Crime and Punishment" Dostoevsky finishes the "incomplete ideas" that are floating on the air" and draws them to their logical conclusions. After all, it was Dostoevsky who once wrote that "nihilism... is the last stage of idealism.".51

\section{References}

ANNENKOV, P.V, The Extraordinary Decade, Literary Memoirs, tr. Irwin B. Titunik, (Ann Arbor, The University of Michigan Press, USA, 1968).

BETHEA, David and Thorstensson, Victoria, "Darwin, Dostoevsky, and Russia's Radical Youth", in Dostoevsky beyond Dostoevsky. Science, Religion, Philosophy, ed. Svetlana Evdokimova and Vladimir Golstein, (Academic Studies Press, Boston, 2016).

CHERNYSHEVSKY, Nikolai, "The Anthropological Principle in Philosophy", in Selected Philosophical Essays, (Foreign Languages Publishing House, Moscow, 1953).

CHERNYSHEVSKY, Nicolai, What Is To Be Done?, tr. Michael Katz, (Cornell University Press, Ithaka and London, 1989).

50 Ivan Turgenev, Fathers and Sons, tr. R. Freeborn (Oxford University Press, UK, 1998), p. 23.

51 Cited in Malcolm Jones, "Raskolnikov's Humanitarianism", p. 41. 
DOSTOEVSKY, Fyodor, Crime and Punishment, tr. David McDuff, (Penguin, UK, 1991).

DOSTOEVKSY, Fyodor, Selected Letters of Fyodor Dostoevsky, ed. Joseph Frank and David Goldstein, tr. Andrew MacAndrew, (Rutgers University Press, New Brunswick and London, 1987). FRANK, Joseph, Dostoevsky, vol. 4, The Miraculous Years, 1865-1871 (Princeton University Press, Princeton, 1995).

JONES, Malcolm, "Some echoes of Hegel in Dostoevsky", The Slavonic and East European Review (vol. 49, no. 117, Oct. 1971).

JONES, Malcolm, "Raskolnikov's Humanitarianism" in Raskolnikov and Svidrigailov, ed. Harold Bloom, (Chelsea House, USA, 2004).

GILLESPIE, Michael Allen, Nihilism before Nietzsche (University of Chicago Press, Chicago, 1995).

KATZ, Michael and Wagner, William, "Chernyshevsky, What is to be Done? And the Russian Intelligentsia", in Nicolai Chernyshevsky, What Is To Be Done?, tr. Michael Katz, (Cornell University Press, Ithaka and London, 1989).

KIBALNIC, Sergei, "'If there's no immortality of the soul,.. everything is lawful": On the Philosophical Basis of Ivan Karamazov's idea", Dostoevsky Beyond Dostoevsky. Science, Religion, Philosophy Science, Religion, Philosophy, ed. Svetlana Evdokimova and Vladimir Golstein, (Academic Studies Press, Boston, USA, 2016).

LEOPOLD, David, "Introduction", in Max Stirner, The Ego and Its Own, tr. Steven Tracy Byington, ed. David Leopold, (Cambridge University Press, UK, 1995).

PEACE, Richard, "Nihilism" in A History of Russian Thought, ed. William Leatherbarrow and Derek Offord, (Cambridge University Press, USA, 2012).

PEREIRA, N.G.O, "Challenging the principle of Authority: The polemic between Sovremennik and Russkoe Slovo, 1863-1865", The Russian Review (vol. 34, no2, April 1975).

TOEWS, John Edward, Hegelianism. The path toward dialectical humanism, 1805-1841 (Cambridge University Press, USA, 1980).

SHIMIZU, Takayoshi, "Dostoevsky and Max Stirner", paper given at the XIV International Dostoevsky Symposium, Naples, 
Italy, June 2010, Abstracts, ed. Michela Vendith.

STEPELEVICH, Lauwrence S, "Max Stirner and Ludwig Feuerbach", Journal of the History of Ideas (vol. 39, 1975).

Stirner, Max, The Ego and Its Own, tr. Steven Tracy Byington, ed. David Leopold (Cambridge University Press, UK, 1995).

VENTURI, Franco, Roots of Revolution. A History of the Populist and Socialist Movements in Nineteenth Century Russia, tr. Francis Haskell (Weidenfeld and Nicholson, UK, 1960).

WELSH, John F, Max Stirner's Dialectical Egoism, A New Interpretation (Lexington Books, UK, 2010).

Recebido em: 04/07/2020

Aceito em: 27/07/2020

Publicado em setembro de 2020 